\title{
The Relocation Planning for Shanghai Distribution Center of Express Company
}

\author{
Jing Sun and Guang Cheng*
}

Department of Industrial Engineering and Logistics, Beijing Union University, Beijing, 100020, China

\begin{abstract}
Rapid increasing logistics demands call for high efficiency delivery in cities. Effective city planning of distribution centers is crucial. This paper first analyzes the current situation and constraint of Shanghai distribution centers. Then investment proposal is made for Shanghai distribution center relocation. The facility site selection and layout plan are proposed, and the commitment is calculated. Lastly sensitivity analysis is provided. Proper relocation planning will be helpful to fulfill the increasing market requirements.
\end{abstract}

Keywords: Distribution center, express company, planning, relocation.

\section{INTRODUCTION}

The express industry has developed for several decades rapidly in China. With China's rapidly expanding economy growing, the demand on the express services increases dramatically from both home and abroad [1]. The express companies are bound to improve their service level as a result [2]. In all aspects of customer service, on-time delivery is very critical. Hence, how to effectively plan the distribution center (DC) locations has become a key issue [3]. This can lay the foundations to ensure express company becoming a major player in the fastest growing logistics market in the world.

Shanghai city (SHA) has been recognized by express company as one of the most important cities due to its current global presence as well as its future growth potential. The relocation planning of SHA DC will be helpful for express company to further uplift service level, win big customers from main competitors and explore new sales areas.

\section{CURRENT SITUATION AND CONSTRAINTS}

\subsection{Current Situation}

Currently SHA city has 5 main distribution centers (DCs). There are 2 DCs which cover Pudong district-- one is Kangqiao DC (KQE) covering the most part of Pudong district, the other is Wai Gao Qiao DC (WGQ) with the coverage of Wai Gao Qiao FTZ only; there are 3 DCs covering Puxi district with CBD district DC (ZQC) serving the central business, Hongqiao DC (HQW) serving the business area of SHA west, and Hong Yang DC (YQN) serving the north area. The locations of the existing facilities are marked on the map shown in Fig. (1).

Though a number of distribution centers have been setup in SHA in the past, the total operations capacity of SHA is

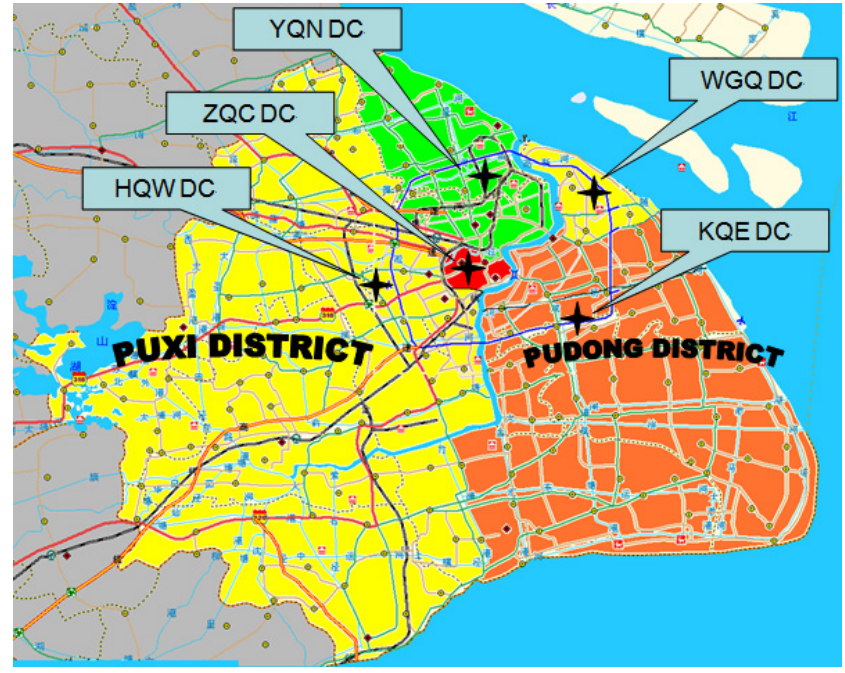

Fig. (1). Current DC allocation of SHA.

still inadequate to support the business needs. In particular, the operations capacity is inadequate to support the shipment volume in Puxi area where HQW DC and ZQC DC are located. There are 79 courier routes based in HQW DC. It has been experiencing congestion problem. So Pujiang DC (PJ) is proposed to relieve the pressure off HQW DC and to provide the needed capacity.

\subsection{Current Constraint}

At present, a number of operations constraints are associated with the existing distribution centers in Puxi area:

- Inadequate operation warehouse and parking space to handle current and projected future shipment volumes.

- No space for future expansion.

- Poor traffic conditions around existing DCs.

- Too much shipment volume (around $40 \%$ of SHA's volume) handled by HQW DC. 


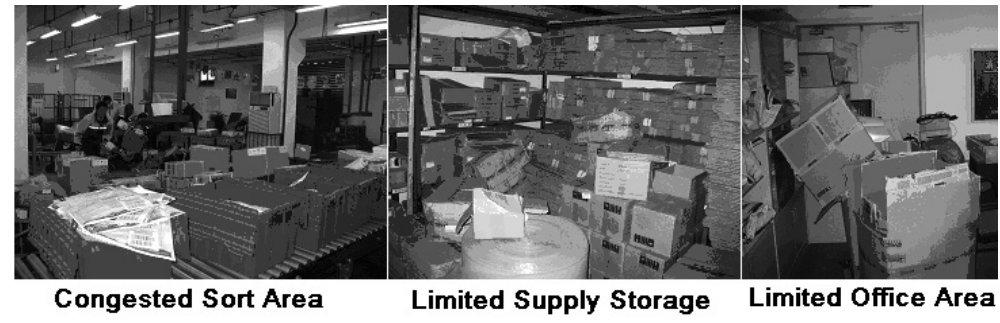

Fig. (2). The operation constraints for HQW DC.

Table 1. The vehicle details planned for PJ DC.

\begin{tabular}{|c|c|c|c|c|c|}
\hline Vehicle Projection & $\mathbf{2 0 1 4}$ & $\mathbf{2 0 1 5}$ & $\mathbf{2 0 1 6}$ & $\mathbf{2 0 1 7}$ & $\mathbf{2 0 1 8}$ \\
\hline \hline Courier Van & 48 & 35 & 40 & 50 & 6 \\
\hline Sweeper/Feeder Van & 6 & 4 & 3 & 3 & 3 \\
\hline Shuttle Truck & 3 & 3 & 48 & 54 & 59 \\
\hline Total Vehicle & 57 & 42 & 5 & 5 \\
\hline
\end{tabular}

Table 2. Space requirement.

\begin{tabular}{|c|c|c|}
\hline Analysis Summary & Drive-In & Non Drive-In \\
\hline \hline Gross Administration Area $\left(\mathrm{m}^{2}\right)$ & 467 & 467 \\
\hline Gross Warehouse Area including W/H Admin. $\left(\mathrm{m}^{2}\right)$ & 3701 & 2093 \\
\hline Gross Parking Area $\left(\mathrm{m}^{2}\right)$ & 1055 & 2483 \\
\hline Supply room for $50 \%$ of SHA's need $\left(\mathrm{m}^{2}\right)$ & 500 & 500 \\
\hline Total $\left(\mathrm{m}^{2}\right)$ & 5723 & 5543 \\
\hline
\end{tabular}

- Stem times of some routes are too long due to large geographical coverage of HQW DC's routes [4].

- Inadequate general service area in HQW DC (meeting room, washing facilities, showers, lavatories, changing room, canteen).

Fig. (2) shows the operation constraints for the existing HQW DC facility.

\section{INVESTMENT PROPOSAL}

\subsection{Facility Size and Capacity}

This phase ensures operation infrastructures will be deployed with suitable capacity [5].

The vehicle details planned for PJ DC is shown as Table $\mathbf{1 .}$

The facility is sized for both international express and domestic express operations. The design year is Y2018. Space requirements for both Drive-In and Non Drive-In operations are summarized as Table $\mathbf{2}$.

\subsection{Facility Site Search and Selection}

Locating an operation facility in Puxi area has been extremely difficult because Puxi is basically a fully built-up area. Three potential sites have been identified finally.

Fig. (3) shows the locations of those candidates.

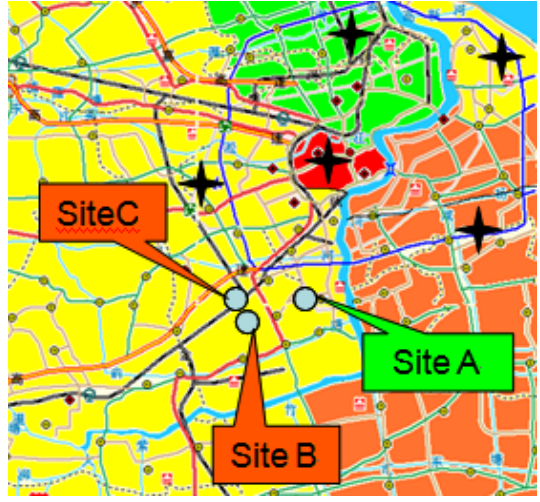

Fig. (3). Candidates of site for PJ DC.

Comparisons among these facilities are summarized in Table 3.

\subsection{Facility Selection}

Among the proposed sites, Site A best suits requirements [6]. The rest of the sites are either too small or of bad traffic conditions.

Fig. (4) shows the exterior view and interior view of site A.

Site A is located in No.2588 South Lianhua Rd., Minhang District Shanghai, approximately $33 \mathrm{~km}$ from PVG 
Table 3. Target site basic information.

\begin{tabular}{|c|c|c|c|}
\hline Landlord & Minhang int'l logistics center & Shanghai JiaJin & AMB Property Corporation \\
\hline Area for Office $\left(\mathrm{m}^{2}\right)$ & 0 & 0 & 970 \\
\hline Structural Area & 9504 & 2600 & 2910 \\
\hline Ceiling Hight (m) & 5.5 & 6.0 & 3.5 \\
\hline Distance to PVG (km) & 33 & 35 & 45 \\
\hline Unit Price (RMB/m²/Day) & 1.04 & 0.70 & 0.50 \\
\hline Remark & $\begin{array}{l}\text { 1. License available. } \\
\text { 2. Good image. } \\
\text { 3. Can rent based on our requirement. } \\
\text { 4. Close to our customers. }\end{array}$ & $\begin{array}{l}\text { 1. License available. } \\
\text { 2. The surrounding is very bad, may } \\
\text { be relocated by gov. } \\
\text { 3. Area for warehouse is } 1300 \mathrm{~m}^{2} \\
\text { only, } 2600 \mathrm{~m}^{2} \text { is two warehouse size. } \\
\text { There are } 2 \text { meters between them. }\end{array}$ & $\begin{array}{l}\text { 1. The ceiling hight is very low. } \\
\text { 2. The size of first floor is small. } \\
\text { 3. The hight between inside and } \\
\text { outside are very high, no way to DI. }\end{array}$ \\
\hline
\end{tabular}

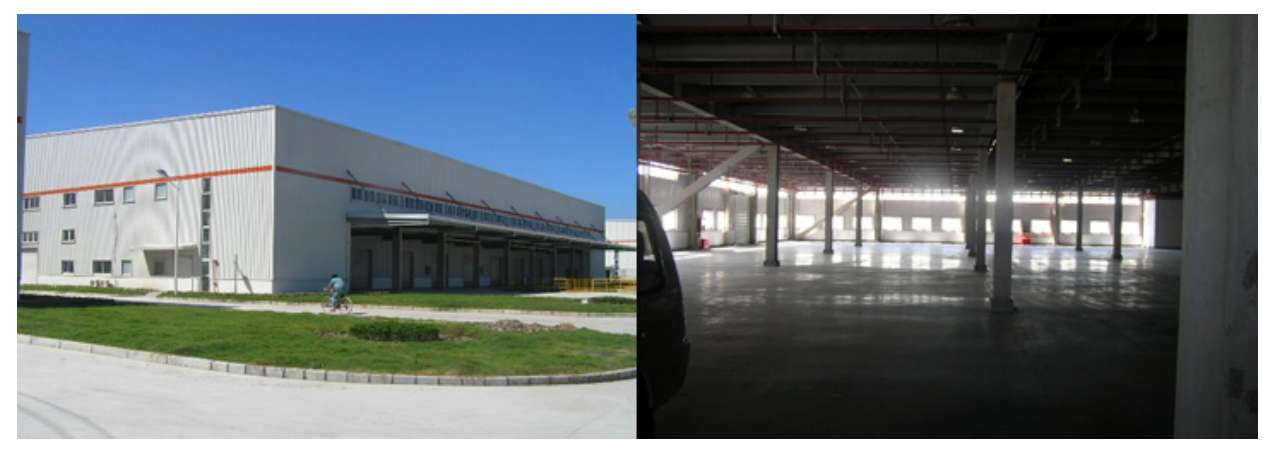

Fig. (4). Facility photos of site A.

gateway. The warehouse has a building footprint of $72 \mathrm{~m} \times 66 \mathrm{~m}$ and a total floor space of $9504 \mathrm{~m}^{2}$ (2 floors, excluding parking area).

Site A is strategically located nearby the Xupu Bridge which spans the Huangpujiang river, and the expressway outlet, that help reduce the trucking time to/from PVG gateway, making delivery sooner and outbound cutoffs later. This site is also close to the existing clientele around the CBD, Puxi area, which ensure optimal routing of shipment flow i.e. there is no backward pass of traffic. Good accessibility to the major service areas further shortens courier stem time.

The attractiveness of this proposed site includes:

- Ample outside parking area.

- Location near the main expressway and highway.

- Warehouse size suitable for Drive-In concept operation.
- Landlord's willingness to allow company to renovate the building to operational requirements (i.e. knock down walls, excavate, pit, etc.)

- Sufficient floor space for intended design requirements.

- Sufficient warehouse space for based on the forecasted design requirements.

A comparison of the Actual Vs Calculated Sized Requirements can be seen in Table 4 .

\subsection{Facility Layout}

The new facility will be fully standard operation procedure compliant and a layout plan showing the arrangement of the offices and the operational areas, including the flow line, can be found out in Figs. (5 and 6).

Both international and domestic shipment volumes have been taken into consideration in the facility sizing. 
Table 4. The actual vs calculated sized requirements.

\begin{tabular}{|c|c|c|c|}
\hline Analysis Summary & Drive-In & Non Drive-In & Actual Sizing \\
\hline \hline Gross Administration Area $\left(\mathrm{m}^{2}\right)$ & 467 & 467 & 492 \\
\hline Gross Warehouse Area including W/H Admin. $\left(\mathrm{m}^{2}\right)$ & 3701 & 2093 & 3822 \\
\hline Gross Parking Area $\left(\mathrm{m}^{2}\right)$ & 1055 & 2483 & 500 \\
\hline Supply room for 50\% of SHA's need $\left(\mathrm{m}^{2}\right)$ & 500 & 5543 & 500 \\
\hline Total $\left(\mathrm{m}^{2}\right)$ & 5723 & 5935 \\
\hline
\end{tabular}

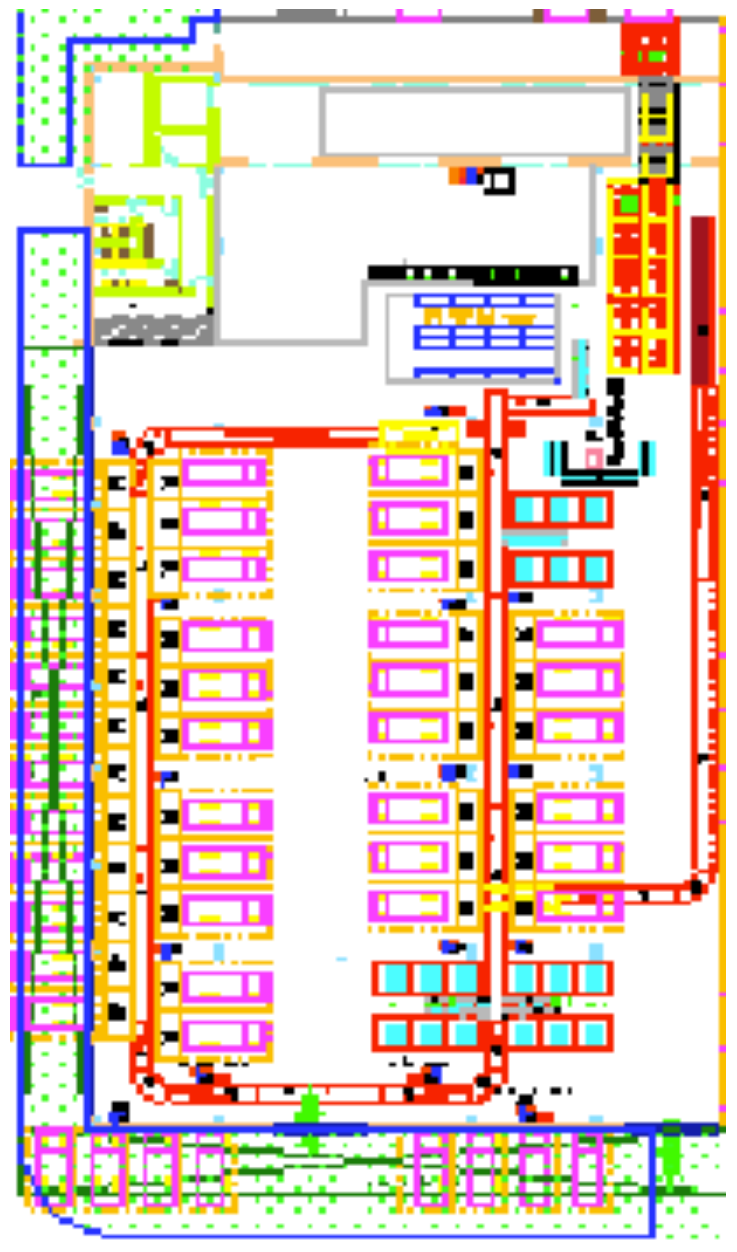

Fig. (5). The 1st floor layout.

The proposed facility is a 2-storey building. Left half of the first and second floor is to be rented. Each part is a footprint size of $2407.2 \mathrm{~m}^{2}$ and the total area is $2407.2 \times$ $2=4814.4 \mathrm{~m}^{2}$. It is suitable for a DC to handle the volumes and couriers planned for this facility.

Due to some minor vehicle accessibility constraints, and the need to optimize the use of both internal and external floor space, the proposed layout is of a "Hybrid" type i.e. a combination of Drive-In and Non Drive-In couriers. In the layout submitted 38 vans have the ability to park in this facility. The remaining 18 Non Drive-In couriers would need to park their vans outside.

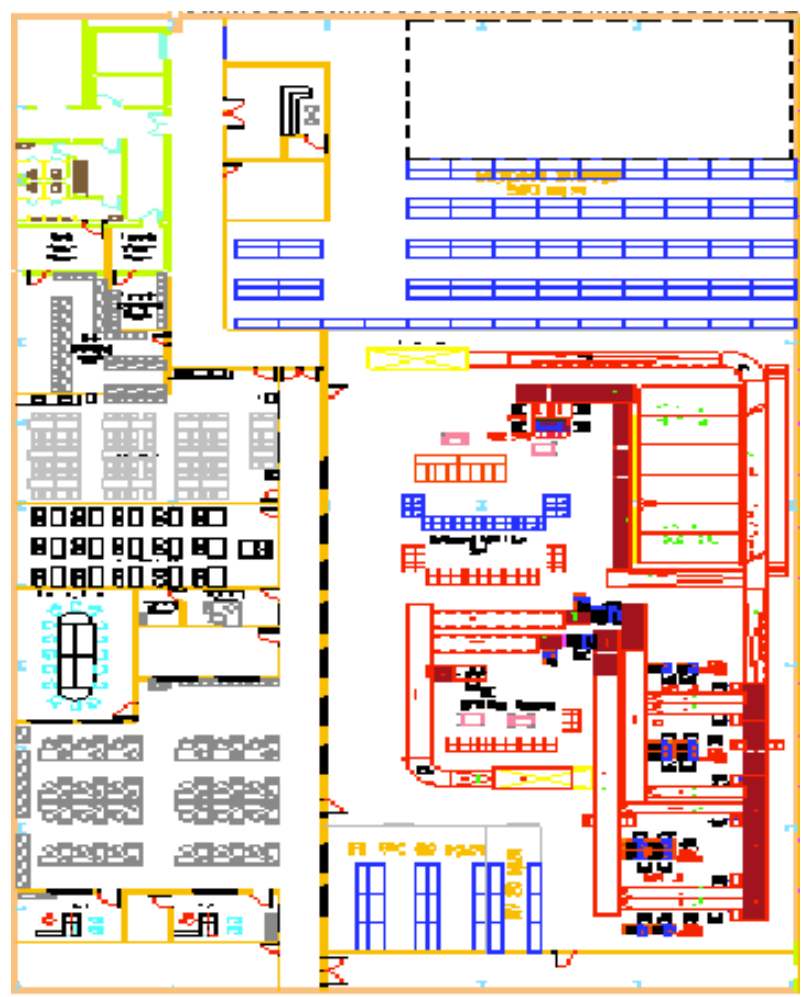

Fig. (6). The 2nd floor layout.

The reasons for a "hybrid" are:

- Having the ability to park vans in the warehouse has great advantages such as improved productivity by minimizing double handling (especially for Feeders and Sweepers), shipment protection from the elements as well as portraying a professional image.

- As the actual site has limited outside parking areas, therefore parking inside the warehouse reduces the amount outside. There are shuttle trucks and office cars parking outside as well.

\subsection{Workforce}

Table $\mathbf{5}$ is the labor requirement forecast for SHA PJ DC.

\section{EXPECTED BENEFITS}

With the opening of PJ DC, the following operational and business benefits will be realized [7]: 
Table 5. The labor requirement forecast for SHA PJ DC.

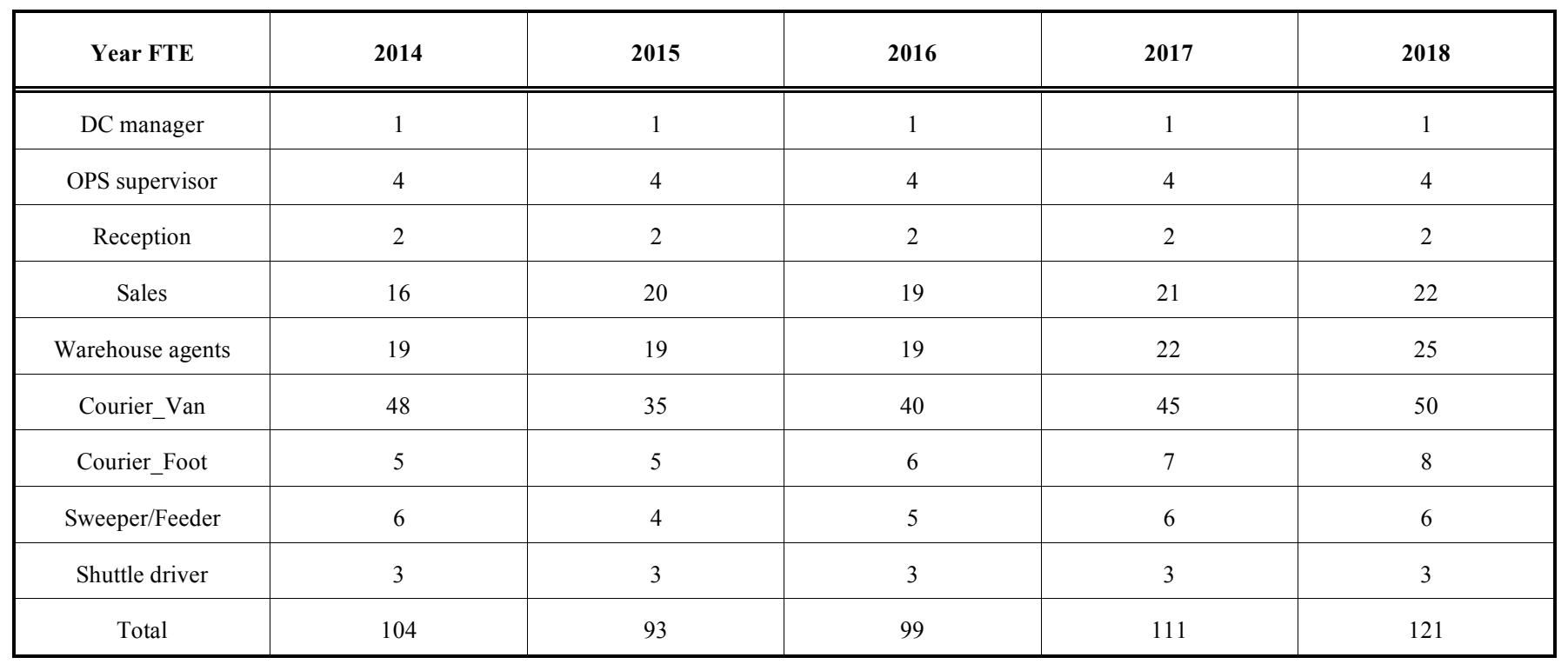

- The alleviation of the capacity constraints in SHA operations

- Improved capability and capacity of processing to support the existing and future business

- Improved service to customers through a more efficient operations centre; improved courier operations efficiency with proper unloading/loading shipment handling equipment, proper parking area and reduced vehicle congestions

- Shorter trucking time from Puxi area to the gateway with good accessibility to major roads and express way

- Compliance with corporate image and improved working conditions

- Improved safety for all employees

- Better protection of customer shipments with more sheltered courier van operations in the warehouse

- HQW DC routes could be transferred to the proposed PJ DC in time before the evacuation deadline for HQW DC

\section{COMMITMENT CALCULATION}

Total commitment for PJ DC is Euro 1912K shown in Table 6.

- The Rental cost of Euro 916K calculated on the basis of leasing $4814.40 \mathrm{~m}^{2}$ of facility (at Euro $0.104 / \mathrm{m}^{2} /$ day) for a term of 5 years.

- The leasehold improvement cost is Euro 343K.

- The leasehold improvement includes the renovation and modifications to the base building. This cost includes smashing walls and installing roller doors for the warehouse.

- The Technical Equipment and Machinery is required to operate a TSP compliant facility and includes MHS
Table 6. Total commitment for SHA PJ DC.

\begin{tabular}{|c|c|c|}
\hline Commitment & $\begin{array}{c}\text { Amount } \\
\text { (EUR) }\end{array}$ & $\begin{array}{c}\text { Asset Life } \\
\text { (Years) }\end{array}$ \\
\hline \hline Leasehold Improvement & $334 \mathrm{~K}$ & 10 \\
\hline Rental & $916 \mathrm{~K}$ & 5 \\
\hline Machine and Equipments & $434 \mathrm{~K}$ & 10 \\
\hline MIS equipment & $185 \mathrm{~K}$ & 5 \\
\hline Furniture & $25 \mathrm{~K}$ & 8 \\
\hline Office Equipment & $9 \mathrm{~K}$ & 10 \\
\hline One-off Cost & $8 \mathrm{~K}$ & \\
\hline Total & $1912 \mathrm{~K}$ & \\
\hline
\end{tabular}

(Material Handling Systems), WDL system, roller conveyors, sorting equipment, security systems, alarm, access control, fire protection, etc. The cost is Euro $434 \mathrm{~K}$.

- The MIS cost includes PABX, routers, hubs, PCs, printers, CCTV etc. The cost of Euro 185K is estimated by IT department. A UPS system will also be installed to ensure continuity of power supply to MIS equipment.

- Furniture and Fittings includes office equipment, furniture, locker room, etc. The cost is estimated to be Euro $35 \mathrm{~K}$ based on area procurement's quotation.

So it is proposed to invest Euro 1912K in SHA PJ DC infrastructure for renovation and procurement of operating equipment, and operating lease. The intended lease period is for 5 years (with an option to renew at the end of the lease term). The investment proposal is to lease and fit out the property to a TSP standard, and transfer 43 routes and some sales personnel from HQW DC to the proposed PJ DC. 
Table 7. Budget link (PJ DC).

\begin{tabular}{|c|c|c|c|}
\hline Item & $\begin{array}{c}\text { Commitment } \\
\text { (EUR) }\end{array}$ & $\begin{array}{c}\text { Budget } \\
\text { (EUR) }\end{array}$ & $\begin{array}{c}\text { Variance } \\
\text { (EUR) }\end{array}$ \\
\hline \hline Commitment--Capital Expenditure & $987.8 \mathrm{~K}$ & $849.5 \mathrm{~K}$ & $-138.3 \mathrm{~K}$ \\
\hline Commitment--Rental Cost & $916.0 \mathrm{~K}$ & $1144.3 \mathrm{~K}$ & $228.3 \mathrm{~K}$ \\
\hline Commitment--One-off Cost & $8.4 \mathrm{~K}$ & $0.0 \mathrm{~K}$ & $-8.4 \mathrm{~K}$ \\
\hline Net Commitment & $1912 \mathrm{~K}$ & $1994 \mathrm{~K}$ & $82 \mathrm{~K}$ \\
\hline
\end{tabular}

The proposal comprises the followings:

- The express company enters into a tenancy agreement for the proposed facility.

- Separate SHA shipment volume to SHA PJ DC.

- Renovate the proposed facility according to regional specifications which involves the complete fit out of the building, mechanical and electrical services (airconditioning), UPS, telecommunications equipment, IT cabling, computers and material handling system, office fit out and furnishing.

\section{BUDGET LINK}

There is a budgeted investment Euro 1994K for SHA PJ DC project. Currently total commitment of Euro $1912 \mathrm{~K}$ is almost same as the budget shown in Table 7 .

\section{SENSITIVITY ANALYSIS}

For DC buildup or relocation project, revenue is the most sensitivity factor to impact key investment indicator. Trading cost and DTD cost will change with revenue variance. Hence it is assumed the revenue of "worst case" will drop $10 \%$ against that of "base case". After calculation analysis by investment tool, the compared results under the both cases are shown as follows.

Table $\mathbf{8}$ is the base case:

Table 8. Base case.

\begin{tabular}{|c|c|c|}
\hline Profitability and Risk Indicators & Pre Tax & After Tax \\
\hline \hline $\begin{array}{c}\text { NPV Free Cashflows } \\
\text { NPV Economic Profits }\end{array}$ & 7088 & 5110 \\
\hline Internal Rate of Return (IRR) & $84.34 \%$ & $61.69 \%$ \\
\hline Pay off Period (in years) & 0.99 & 1.72 \\
\hline
\end{tabular}

Table 9 is the worst case:

Table 9. Worst case.

\begin{tabular}{|c|c|c|}
\hline Profitability and Risk Indicators & Pre Tax & After Tax \\
\hline \hline $\begin{array}{c}\text { NPV Free Cashflows } \\
\text { NPV Economic Profits }\end{array}$ & 4000 & 2917 \\
\hline Internal Rate of Return (IRR) & $51.6 \%$ & $38.8 \%$ \\
\hline Pay off Period (in years) & 3 & 3 \\
\hline
\end{tabular}

\section{CONCLUSION}

With the rapid economic growth of Shanghai city, it is very necessary to develop the new infrastructure for PJ DC to caster for the future business requirement. Thus, this paper makes a detailed investment analysis for PJ DC relocation. Site selection is discussed and the facility layout is provided. Then the commitment for the relocation is calculated. In the end, the sensitivity analysis is listed.

It is a very complex project to plan DCs in cities [8]. It is necessary to do a periodical simulation and evaluation of DCs to respond the changeable market demand.

\section{CONFLICT OF INTEREST}

The authors confirm that this article content has no conflict of interest.

\section{ACKNOWLEDGEMENTS}

The study is supported by Funding Project for Academic Human Resources Development in Beijing Union University.

The authors wish to thank teachers in Beijing Union University for their helpful comments and suggestions.

\section{REFERENCES}

[1] Y. Zhang, and J.G. Wei, "Global logistics' situation and chinese logistics' development," China Business and Market, vol. 23, pp. 30-33, 2009. doi:10.3969/j.issn.1007-8266.2009.10.008.

[2] K. Zheng, and X.C. Wang, "Location selection of the fruit and vegetable distribution center based on the maximization of service," Journal of Anhui Agricultural Sciences, vol. 39, pp. 8760-8763, 2011. doi:10.3969/j.issn.0517-6611.2011.14.212.

[3] X.L. Chen, "The application of Excel programming solver to facilities location," Industrial Engineering Journal, vol. 13, pp. 116-118, 2010. doi:10.3969/j.issn.1007-7375.2010.02.025.

[4] J. Sun, and S.H. Dong, "Study on the delivery area optimization and management," Journal of Applied Sciences, vol. 13, pp. 3730-3735, 2013. doi:10.3923/jas.2013.3730.3735.

[5] R. Wang, Y.Q. Xing, and Y. Li,, "Distribution prediction and storage space evaluation methods for beverage distribution centers," Forest Engineering, vol. 28, pp. 107-109, 2012.

[6] K.F. Dong, H.C. Gan, and H.Z. Zhang, "Distribution center location model based on economics and timeliness," Journal of University of Shanghai for Science and Technology, vol. 35, pp. 336-339, 2013.

[7] J. Sun, and X.F. Sun, 2009. "The city planning for service centers of express company," IEEE $16^{\text {th }}$ International Conference on Indus- 
trial Engineering and Engineering Management, vol. 2, pp. 1419$1422,2009$.

[8] Z.Z Jiang, and D.W. Wang, "Model and algorithm of location optimization of distribution centers for B2C E-commerce," Control and Decision, vol. 20, pp. 1125-1128, 2005. doi:10.3321/j.issn:1001-0920.2005.10.009.

Received: April 02, 2015

Revised: May 23, 2015

Accepted: June 06, 2015

(C) Sun and Cheng; Licensee Bentham Open.

This is an open access article licensed under the terms of the Creative Commons Attribution Non-Commercial License (http://creativecommons.org/licenses/by-nc/3.0/) which permits unrestricted, non-commercial use, distribution and reproduction in any medium, provided the work is properly cited. 